\title{
The Voices and Experiences of Vhavenda Women in the Pentecostal Churches in Thohoyandou
}

\section{Lufuluvhi Maria Mudimeli}

https://orcid.org/0000-0002-9242-2918

University of Venda

lufuluvhi.mudimeli@univen.ac.za

\section{Abstract}

This article sets out to unfold stories of Vhavenda women in the Pentecostal church. It discusses their good experiences and challenges encountered as they do ministry. Their rich experiences and voices can inform the way ministry is practised today. Purposive sampling is used to explore the narratives of seven church women sourced from a previously written thesis. The thesis was conducted in Venda for doctoral studies at the University of South Africa, completed in 2011, where data were gathered through semi-structured interviews and a questionnaire with 97 participants. Some findings from the thesis are that women in rural areas are particularly affected by healthy and unhealthy religious and cultural discourses in their daily involvement in the ministry. Apart from looking at the religious and cultural discourses, the article will also investigate how these women find ways of coping with social and religious challenges as they continue in their various ministry spaces. This will add knowledge concerning women, gender and theology by highlighting the specific voices and experiences of Vhavenda women within their contexts and ministry. The article adopts a qualitative approach and is researched theoretically, employing the insights of vhusadzi theology to analyse the findings. Some of the findings in this article are that the lives of Vhavenda women in the Pentecostal church are filled with struggles and uncertainties, as related to church leadership.

Keywords: Vhavenda women; discourses; culture; religion; Pentecostal church; vhusadzi theology

\section{UNISA $\cong$}




\section{Introduction}

\section{Aims and Context}

The aim of this article is, firstly, to describe the voices and experiences of Vhavenda women in the ministry/church, to examine their good experiences and also the challenges they encounter in the ministry/church. Secondly, it is to explore how these women find ways of coping with religious and cultural discourses that influence perceptions held by people about women in the leadership of the church. Thirdly, the article intends to deconstruct the unhealthy religious and cultural discourses in terms of vhusadzi (womanhood) theology, which aims at empowering women and is applicable in an African-South African context. ${ }^{1}$

Participants for this study were selected by means of purposive sampling, whereby data concerning the experiences of women including religious and cultural discourses were obtained through existing literature from a previous study for the researcher's $\mathrm{PhD}$ studies (Mudimeli 2011, 109-130). For purposes of this article, the data utilised from the mentioned study were collected through a questionnaire and interviews with Vhavenda women in the Pentecostal churches. The focus was on the views and experiences of women who are from two Pentecostal churches in Thohoyandou. The questionnaire and interviews were both conducted by the author, using the home language of the participants. Interviews were conducted specifically to follow up on the participants' answers to the questionnaire, in order to gain more information relevant to the study. The questionnaire and interview questions used were formulated to elicit information from the participants and to suit the purpose of the study. Participants were given an opportunity to share their experiences and knowledge on the following questions: 1) The roles played by women in the church-women were asked about their experiences in the leadership of the church, the good experiences and also the challenges they encountered; 2) The effects of religion and culture on the perceptions of women in the leadership of the church-whether religion or even church doctrine and culture affect women's involvement in the church, and if scripture supports or does not support women's involvement in the leadership of the church.

Interviews were conducted by the author and ethical considerations were upheld in relation to the participants. Letters of consent were given and obtained from the participants.

Stories and experiences of participants purposefully selected for this article are from seven women ranging in age between 20 and 74, and all of them are Venda speaking. All seven of the women are from Pentecostal churches in Thohoyandou. Most of them

1 This article is based on a research thesis by Mudimeli L. M. (2011): "The Impact of Religious and Cultural Discourses on the Leadership Development of Women in the Ministry: A vhusadzi (Womanhood) Perspective," submitted at the University of South Africa. 
were unemployed and had little or no theological training. The sample consisted of pastors, pastors' wives, those in or not in leadership positions of the church.

\section{Women Leadership in the Pentecostal Churches}

The Pentecostal movement rose as a result of the Azusa street revival in Los Angeles, when William Seymour, a black minister from Louisiana (with the influence of teachings of Charles Parham) experienced renewal, seeing hundreds of people experiencing conversion, being filled with the Holy Spirit and speaking in other tongues (Langford 2017, 70). His Azusa Street mission became very powerful as it made no distinction among races and genders, men and women, and was led by an African American pastor providing leadership and guidance to the church. Pastor Seymour was involved and worked with women in the leadership of the church. Women like Lucy Farrow, Aimee Semple McPherson and many others followed in the footsteps of Ozman and Taylor; courageous women of God who were not afraid to step out and be used to spread the wonderful message of Pentecost (Simoneaux 2017, 11). At one point, at least six of Azusa's 12-member leadership committee were women (Langford 2017, 71). Langford stated further that these women believed that the baptism in the Holy Spirit gave them empowerment and justification to engage in activities which have been traditionally denied them. During the years, the ministry of women began to fade. In 2003, Assemblies of God in the USA had only $17.4 \%$ of clergy who were female and $3.64 \%$ who were women, serving churches as senior pastors (Clifton 2009, 172). The empowering of women that seemed to accompany the revivalist origins of global Pentecostalism was not sustained over the course of a century (Clifton 2009, 172). Research shows that the leadership of women in the church continues to be subjected to social, cultural and theological forces that restrict their ministry (Clifton 2009; Mudimeli 2011; Nadar 2004).

African Pentecostalism can be described as a part of Christianity in Africa that is influenced by a Pentecostal movement that started in the early church of the Apostles (recorded in the book of Acts 2:1-4), and the Pentecostal movement that started in the United States of America (Kgatle 2017, 4). Kgatle furthermore states that African Pentecostalism is characterised by justification by faith, sanctification by grace, the baptism in the Holy Spirit evidenced by speaking in tongues, divine healing, and the personal pre-millennial rapture of the saints at the second coming of Christ. Speaking in tongues, for both women and men, is evidence that one is filled with the Holy Spirit and is considered to be spiritual.

As per my observation, women are in the majority in the Pentecostal churches in Venda, and specifically in Thohoyandou, like in other churches, but leadership remains a space of the few. Today, women still dominate the pews in mainline churches, African Instituted Churches, Charismatic and Pentecostal churches, but women are, however, absent from the power structures of the churches, which are male dominated (Mwaura 2013, 411). Few women who are in the leadership are prophesying and are being led by the Spirit; some still face rejection, even from their members. The manifestation of the 
Spirit among Pentecostals in general, and women in particular, gives women power and recognition and in concrete ways upward mobility is visible (Gabaitse 2015, 10). In some settings, women's leadership role is more accepted, but in other settings, their roles in church leadership are still restricted. Women continue in ministry, some as evangelists and others in different charismatic ministries, like the laying on of hands for healing, exorcism, and prophesying - even though they do not receive the acknowledgement or titles. There is a dearth of well-documented research on the role that women play in the churches in Venda, more especially in Pentecostal churches. In most churches, women serve as teachers of the kids or in leading other women during their gatherings (Mudimeli 2011, 94). What women mostly preach about, is how to respect a husband, how to raise kids, and how to have a good relationship with the inlaws. All these are good causes, but are not encouraging other women who look up to them how they could also become leaders in the churches where leadership is only reserved for the few. This situation might be as a result of inadequate training or a complete lack of training.

When Resane $(2018,9)$ wrote about "The Centenary of Assemblies of God in South Africa: Historical Reflections on Theological Education and Ministry Formation," he said that most women who went to Bible school were trained in Sunday school teaching or working with other women. The prevailing practice in Venda, including Thohoyandou, is that women are moving out of denominations and starting their own ministries, where they become leaders and continue to serve under the leadership of the Holy Spirit. Just when one thinks now there is freedom in the church for women to become leaders, debates about what the Bible actually says mushroom again, based on the negative perceptions that people hold about women in church leadership. These perceptions lead to endless debates on whether women are qualified and endorsed by the Bible to occupy positions of leadership in the church or not (Mudimeli 2011, 167). The question that remains, is whether women in the Pentecostal churches are enjoying the freedom to be in leadership positions, like becoming pastors, occupying executive positions in the church, and being leaders in the organisation?

The experience of being filled with the Holy Spirit is not only practised by males in the church; both females and males speak in tongues as a sign of being spirit filled. Mudimeli (2011, 163-164) argues that the following is worth mentioning concerning the experience of Pentecost in Acts 2:1-4:

- The experience involved both women and men.

- All were empowered to become witnesses.

- All were baptised, including the women.

Based on the above, both women and men were spirit filled and given utterance by the Holy Spirit. It is interesting though, as observed from the abovementioned, that even though women are filled or baptised with the Holy Spirit, they are still waiting for the time when the texts that silence them (like 1 Corinthians 14:34-35 and 1 Timothy 2:11- 
15) will be interpreted in line with the guidance of the Holy Spirit (Mudimeli 2011, 165). If women speak in tongues as given utterance by the Holy Spirit, but they have to wait for somebody else to interpret it, the wait will be too long. As yet, nobody is interpreting the tongues that women are speaking related to their leadership in the church. After speaking in tongues, women should listen to what the Holy Spirit is saying concerning these texts and should interpret them as they are given guidance and utterance by the same Holy Spirit. Once filled with the Holy Spirit, Pentecostal women are able to transcend gender limitations imposed on them by Pentecostals' biblical interpretations and practices (Gabaitse 2015,11). When deliberating about women in ministry, however, it is necessary that Pentecostals follow the guidance of the Spirit who uses women in all kinds of ministry and in many instances effectively, along with their reading of the Bible in terms of what the Spirit reveals about the church and ministry (Nel 2017, 9-10).

Pentecostals listen to the Spirit while reading the biblical witness and they interpret it through what they perceive God wants to say to them in their specific situation and what they experience as his revelation in their situation (Nel 2017, 12). The reading of the Bible and the interpretation in the Pentecostal church seem to be very problematic when it comes to the leadership of women. A literalistic reading of the Bible is mostly preferred amongst other readings. This type of reading interprets the text in a literalistic sense without considering the context. This is captured well by Dube $(2015,5)$ when she says that a literalistic reading of the Bible is the kind that takes the Bible at face value, uncritically claiming that the "Bible says it and I believe it." Dube furthermore states that Pentecostal literalistic readers do not take into consideration that texts which seem to support the marginalisation of women, have a history; they emerge from particular and specific Jewish, Greco-Roman and other patriarchal cultures. When the Bible is read in a literalistic, prescriptive sense, where no room is left for its historical situatedness and context-oriented meaning because the Bible is granted the status of final authority on all issues, the ministry of women cannot but be excluded from the church (Nel 2017, 7).

Patriarchy continues to define how women should be treated in the church. It has defined women as inferior, thus perpetuating the marginalisation and oppression of women. The resultant unequal gender relations have translated into male dominance and female subservience in church and society (Mwaura 2013, 412). Pentecostal women face challenges ranging from the perceptions that people hold regarding women and the biblical interpretations that feed the problem religious and cultural discourses that relegate women to a lower status (Mudimeli 2011, 167). Men speak about the freedom that women are having in the church, referring to only a few instances where women have featured preaching or rendering some kind of services. The church is still so much in the hands of men. Men do not look ready to share the power and the ministry that bestows power on them, and this leads many women to no longer pursue ministry in the church. This is attested to by Mkhwanazi and Kgatla $(2015,181)$ while researching the place of women ministers in the mission of the Methodist Church of South Africa, 
arguing that the rejection of ordained ministry by their male counterparts, the African culture's depreciating view of women and biblical texts that support such stereotypes, lead to many women leaving the church, and others choosing to no longer pursue further studies after ordination. Furthermore, Mkhwanazi and Kgatla $(2015,194)$ state that one would expect attempts from male members, in particular, to be seriously engaged, and one would expect a fierce struggle to eliminate any form of discrimination against women in the church.

In a study conducted in 2011 (Mudimeli 2011), on which this article is based, one of the women said that in almost all the churches with which she was familiar, most of the adherents were women. According to her, in reality, the church is the domain of women. Ironically, although women have been in the church all this time, the church does not seem to want them as leaders.

\section{A Conceptualisation of Vhusadzi Theology}

Vhusadzi theology is a theology that has developed from my thesis for a doctoral degree at the University of South Africa between 2002 and 2011 (Mudimeli 2011). From the thesis, it started as a vhusadzi approach. As its point of departure (as vhusadzi approach), it has drawn from the insights of social construction and post-structuralist theories. The study has taken into cognisance the works of feminist theology, womanist theology, African women theologians, and more specially, the bosadi approach. As a student, I became aware and acquainted with the works of a biblical scholar, Madipoane Masenya. The Bosadi approach, as coined by Masenya (1996), has influenced the development of vhusadzi theology. I applied its insights in the context of systematic theology. Taking into account the scope, context and realities of the bosadi approach, one cannot refute that this is an approach/perspective that is closer to African-South-African women than the other liberation theologies. Here is Masenya's argument concerning the bosadi approach:

The bosadi approach is not simply a comparative analysis between the biblical text and the African culture. It critiques both cultures and texts not only in terms of gender concerns. It also includes issues of class, "woman-as-strange" and "African-as-strange" in their own territory. (Masenya 2005, 745)

There are similarities as well as differences between what Masenya presented regarding the bosadi approach and what vhusadzi theology presents. The most obvious similarity is that the word bosadi is Northern Sotho, while vhusadzi is a word in Tshivenda. As much as people in South Africa are not the same, though staying in the same country, the same applies to women. There might be many similarities, more especially amongst women of the same race, but there are also differences. That is the reason I decided to call it vhusadzi in my context. The word vhusadzi, which is literally bosadi, offers the Venda Christian woman the tools for deconstructing the faces of both cultural and religious discourses that are harmful to women's lives. African indigenous languages are rich with words and expressions which not only speak to local concerns, but also 
relate to global concerns. When Masenya coined the concept bosadi, she did not have only national and continental concerns in mind, but also global concerns (Masenya 2005, 746). The richness and the relevancy of the bosadi approach in restoring AfricanSouth African women's dignity have influenced me in developing vhusadzi, as stated in my thesis (Mudimeli 2011, 44). It is the intention of vhusadzi theology to make use of similar insights and strategies as laid bare by Masenya, while focusing on developing it in terms of its relation to God (or teachings about God), the person of Christ (Christology), the Holy Spirit, the church and women's leadership roles in the church. Furthermore, vhusadzi theology will seek to make suggestions for changing the oppressive nature of the language used by the church:

- To engage critically with the patriarchal Pentecostal church's status quo with a view to investigating how affirming it is to the issue of the leadership of the Vhavenda women.

- To check the extent to which the legacies of the colonial and apartheid government continue to play a role in the policies and practices of the church with regard to the leadership of women.

- To engage critically with the role that the African culture has played and continues to play in the marginalisation and non-affirmation of women with regard to the issue of leadership.

- To engage critically with the role of religion, in particular, the Christian religion and its sacred texts in both the marginalisation and affirmation of women in leadership (Mudimeli 2011, 53).

What exactly does vhusadzi theology do? From my previous studies (Mudimeli 2011; Mudimeli and Landman 2014; Mudimeli and Van der Westhuizen 2019) and in this context, this is what vhusadzi theology is aiming to achieve, as summarised below:

- Empowering women through deconstructing the problematic and cultural discourses that are harmful to women and more especially as they relate to church leadership.

- Resuscitating and recapturing the reality of black African-South-African Muvenda woman in finding ways to speak about their experiences in God and in describing their ecclesiastical struggles in order to shape their present and their future. This is to look back into their/his/her stories with hope to tap from them the building blocks in taking a step forward.

- Making a link between religion, culture and ministerial/church leadership with a gender focus that produces new knowledge on the relationship between religion and culture as it manifests itself in a Venda context.

- Contextualising issues pertaining to women and church leadership, thus bringing the message of the Bible to their situations, so that rural Bible readers who most of them have little or no theological training, can find meaning and a better understanding of the Bible. 
After giving a summary of the developments of vhusadzi theology and what it is about in this article, what then are the women saying about their experiences in the Pentecostal church?

\section{Findings and Discussion}

\section{The Voices and Experiences of Women in the Church}

This section looks at the voices and experiences of Vhavenda women in the Pentecostal church in order to achieve the aim of this article, which is, firstly, to describe the voices and experiences of Vhavenda women in the ministry/church, their good experiences and also the challenges they encounter in the ministry/church. Secondly, it is to explore how these women find ways of coping with religious and cultural discourses that influence perceptions held by people about women in the leadership of the church. Thirdly, it is to deconstruct both the unhealthy religious and cultural discourses in terms of vhusadzi (womanhood) theology, which aims at empowering women and is applicable in an African-South African context. Participants were given an opportunity to share their experiences and knowledge of the following questions: 1) The roles played by women in the church-women were asked about their experiences in the leadership of the church, the good experiences and also the challenges they encountered;2) The effects of religion and culture on the perceptions of women in the leadership of the churchwhether religion or even church doctrine and culture affect women's involvement in the church, and if scripture supports or does not support women's involvement in the leadership of the church. The findings are divided into three sub-sections:

- Women against women's leadership in the church.

- Women supporting women's leadership in the church.

- Religion and culture's effects on women in the church.

The above sub-sections will be analysed through the lens of vhusadzi theology as an empowerment theology to Vhavenda women in the ministry/church.

\section{Women against Women's Leadership in the Church}

The first question asked was about the roles of women, women's experiences in leadership opportunities and the challenges they encountered. The views of women concerning the first question were different. Amongst them, there were those who never thought women could play any leadership role in the church, and there were those who felt women should lead. This latter group supported women's ordination in the church. This section will first concentrate on those who were against women in leadership or women's ordination. From the participants who answered the questionnaire and those who were interviewed, $15 \%$ of women indicated that scriptures like 1 Timothy 2: 8-15 deny women leadership in the church; as such they did not support the leadership of women in the church (Mudimeli 2011, 118-131). They stated that the actions of women contradicted what the Bible decreed regarding ordination. It is noted that scriptures like 
1 Timothy $2: 8-15$ are the ones that are used to deny women leadership in the church.

Vhusadzi theology, as a theology of empowerment to women, would always encourage both women and men to read and preach on scriptures like Galatians 3:28, "there is neither Jew nor Greek, there is neither slave nor free, there is neither male nor female; for you are all one in Christ Jesus" (NKJV). This text encourages inclusive ministry in the church, a ministry where both women and men serve the lord without discrimination and limitations. If the Pentecostal church could be open to the change and transformation that the Holy Spirit can usher, the marginalisation or exclusion of women is inimical, as the Holy Spirit is able to destabilise and threaten patriarchal ideology and prerogatives (Gabaitse 2015, 11).

Women who are not supporting women in becoming pastors, argue that because Jesus had no women apostles, he did not intend women to occupy leadership positions. The argument raised by these women is used to deny women leadership roles in the church. If one argues that there were no black people amongst the apostles of Jesus (and more specifically black men), would this lead to black men leaving positions of leadership in the church? It is noted with sadness, though, and very unfortunate that it is not only men who are not supporting the leadership of women in the church, but also women. It is disappointing and not empowering that even women do not support the leadership of women in the church. When probed more on this, some participants replied that they preferred to be pastored by men instead of women. Some reasons provided by these women, as stated in Mudimeli $(2011,120)$, are that women:

- Were not able to handle pressure.

- Shouted at people or members of the church easily when under pressure.

- Were unpredictable (today they are happy; tomorrow one cannot say what went wrong).

- Spoke badly about each other.

- Undermined each other.

- Were easily irritated and could not take a stand about matters (meaning they could not think for themselves).

\section{Women Supporting Women's Leadership in the Church}

Women who supported women assuming a leadership role in the church (Mudimeli 2011, 120-131) were those women who were in leadership positions themselves (those who believed they had a calling in their lives to assume a ministerial role in the church). These women said that God had called them to be in the ministry/church. Therefore, they felt that they did not call themselves to the ministry, nor were they emulating what was happening in the government where women were appointed as cabinet ministers and in other important posts. They asserted that they had been in the ministry before democracy was born in this country. Their involvement in the ministry should not be viewed as being in the ministry so that they can represent women in general. 
Accordingly, women strongly felt that they did not want to be in the leadership of the church to make up the numbers or balance out the ratio of women to men; they wanted to be there because they felt they had been mandated by God to fulfil the will of God in and through their lives. Speaking as a musadzi (woman), one would state that women's leadership positions in the Pentecostal church should not be supported on the basis of what is happening in a democratic state, but rather on what the Holy Spirit is saying to the church. Pentecostals' support of non-discrimination on the basis of gender and age should not rest on the modern culture of human rights, but on the egalitarian impulse that characterised the early Pentecostal movement as well as its predecessors and the early church $(\mathrm{Nel} 2017,13)$. Nel furthermore states that the Spirit will lead them to treat all people the same, as happened in the ministry of Jesus, and they will find confirmation for their behaviour in scriptures when they read it from their perception of the way the Spirit guides them.

The participants (Mudimeli 2011, 120-131) who stated that women should be leaders and should be in partnerships with men in the ministry, indicated that if women claimed that they had been called (just as men claimed that they were), then they should receive equal treatment. Therefore, the church should find a way of accepting women in leadership positions. Furthermore, they should be able to find ways of working together as they are both called to do the same work. It is important to note that participants stated that women who were becoming church leaders should be strong, as they were entering a field which had been previously closed to them. A Vhusadzi theology as a life-giving theology, encourages women to collaborate and network with men; this is a sign that women are not using violent measures to achieve recognition.

Women who were in favour of the leadership of women in the church said that the contribution and the works of Vhavenda women in the ministry are not well known. They argued that most ministries that were flourishing in their localities, had been founded by women. Women stated that churches which recognised women in ministry and gave them opportunities to be pastors, were effective in their ministries. They argued that women had been part of the church since its inception; therefore, it was an injustice that their contributions had not received any recognition. It is very interesting, yet not impressive for vhusadzi theology, to observe that women's contribution in African-South-African Vhavenda churches is not well known and documented. Vhusadzi theology encourages that the works and contribution of women in the church should be recognised and well documented and this will form part of her/history in the church.

\section{Religion and Culture's Effects on Women in the Church}

The second question was on the effects of religion and culture on the perceptions of women in the leadership of the church, whether scripture supports or does not support women's involvement in the leadership of the church. Amongst the women who were not in support of women becoming pastors, as also observed above, they referred to 
scriptures and culture to prove that women are not supposed to lead. Some of the women supported the idea that there is no biblical proof of a woman serving as a pastor, since Jesus only called men to become his disciples. They further alluded that Paul said women should learn in silence, and therefore were of the opinion that there is no need for women to assume positions of leadership in the church. Scriptures like 1 Timothy 2:8-15 and 1 Corinthians 14:34-35 are used to silence the voices of women in the church. When these scriptures are read, they are used to silence the voices of women and are intended for women not to dare dream about themselves becoming pastors. Some religious discourses revealed by the participants are as follows (Mudimeli 2011, 129):

- Women are inferior and subordinate to men.

- Women are not equal to men.

- Women cannot lead.

Religious discourse plays a significant role in silencing the voices of women in the church and in assuming leadership. Women have to prove unequivocally that they are really called and that they heard the voice of the Holy Spirit. Women who fail to prove their call are subjected to rejection, isolation, frustration and doubt.

Vhavenda culture possesses both positive and negative elements. Most proverbs and rituals with implications for women indicate the subordinate position of women in society. Many practices which are embedded in culture, like a preference of sons, gender-based violence, women's domestic roles, and land ownership are capable of restricting women to fulfil positions of leadership and power. Women stated that the language of proverbs, which relates to women, gives men an advantage over women and stresses that a man is naturally born a leader (Mudimeli 2011,117). The patriarchal nature of Vhavenda culture is such that women cannot lead men. Being patriarchal, the church finds a basis in culture to subjugate women.

The views shared by participants who supported women leadership in the church, are as follows (Mudimeli 2011, 119-120): women are frustrated because they are also called, but their calling is not validated in the local church. Those who wish to pursue their calling will have no choice but to leave the church and join congregations where women are encouraged to be pastors. Another alternative, as a common practice today, would be to start a new ministry. Even when women are teachers of the Sunday school, youth and women ministries, they are not recognised as pastors. A vhusadzi theology is challenged by this type of patriarchal thinking, because women remain voiceless and could not be sent to be pastors specifically in this church and in the churches that uphold the same teachings. This is rightfully observed by Masenya when she said:

In our everyday lives, those who possess a voice are those on top, those with power. Such people occupy the upper layers of our societal pyramids. Conversely, those at the bottom of our societal pyramids are usually voiceless, with no legitimated power, like women in a patriarchal context. (Masenya 2012, 205) 
On the basis of the above, it is observed that religious and cultural discourses are problem discourses as voiced by women and observed through their unique experiences. It is also observed through a vhusadzi theological lens that women have to prove unequivocally that they are really called by God and that they are doing what they are doing because it is God's calling for them (Mudimeli and Landman 2014, 274). This is also attested to by Landman in her project of (de)construction of religious identity in oral history research in South Africa:

Furthermore, the project placed gender roles in society and in the church on the table, creating space for religious and community leaders for future discussions. Above all, the project points to the reign of a stubborn patriarchal gender identity and how it is being fed by harmful religious discourses on divine manhood on an ongoing basis. (Landman 2013)

The voices and experiences of women in this article and looking at them from a vhusadzi theological view point (full details and findings in Mudimeli 2011, "The Impact of Religious and Cultural Discourses on the Leadership Development of Women in the Ministry, a Vhusadzi (Womanhood) Perspective") have found that the leadership of women in Pentecostal churches in Venda is faced with challenges, which include:

- Rereading the Bible from the perspectives of women in partnership with men.

- Validating women's ordination in dialogue with the patriarchal interpretations of presumed biblical prohibitions on women's ordination.

- Rescoping cultural influences on church leadership roles, which are supported by Venda proverbs and rituals and reframing perceptions of women in ministry among church leadership and the laity.

\section{Vhusadzi Theology on Rereading the Bible and Validating Women's Leadership}

The rereading of the Bible by women and with women in the Pentecostal church is imperative. A vhusadzi theology rereading of the Bible will not take for granted religious discourses that are harmful to women, but will assist in creating new ones that are healthy. In most instances, the Bible is read to women and about women, but without women being involved. As a musadzi (woman) Bible reader, I have observed that those who read the Bible (as in preaching by men in the churches) take advantage of the majority of the adherents in the church, who are women. Mostly, the Bible is read to endorse patriarchal perceptions that continue to do harm to the lives of women.

The lack of acceptance given to women frustrates more now than when it was a wellknown factor that women are not welcomed. One is more able to deal with an enemy which is visible, that one who is hiding. It seems like the church is playing "hide and seek" with the position of women. Should women still remain silent in the church, and if they have anything to say, should they ask their husbands at home? Can the Holy Spirit speak through women themselves on how they should be accepted into leadership positions? From a vhusadzi theological perspective, and on the basis of the voices and 
experiences of women as described above, women should rewrite their experiences moving from being victims and becoming change agents of their own lives. Of significance, women should read the Bible and get exposed to what it says by themselves, becoming active actors in the shaping of their lives. This will bring about new experiences and new voices of women in the church. New voices of women in the Pentecostal church in Thohoyandou will emerge and be heard from women themselves. New experiences (that are not shaped by perceptions that hold them captive to injustices, not only of sexism, but also of classism, racism, culture and landlessness) will find new meaning as women become agents of change, shaping their lives for the present and the future. All the readings that have been done to them should be evaluated from the women's perspectives. Elsewhere I argued that Vhusadzi theology encourages women to study the Bible and deliberately use texts that empower them (Mudimeli and Van Der Westhuizen 2019, 125), and this article contends that if the Bible can be used as a weapon to disempower women, it can also be used to empower them.

\section{Conclusion}

This article described the stories and experiences of Vhavenda women in the Pentecostal church, that their lives are affected by unhealthy religious and cultural discourses about their position when it relates to leadership. I have highlighted that women have to prove unequivocally that they are called into the ministry and that they heard the voice of the Holy Spirit. The findings reveal that the leadership of women is still a debatable issue in some of the Pentecostal churches in Thohoyandou, as observed from the experiences of the women above. I have demonstrated and emphasised ways in which women can become agents of their own change, as viewed from vhusadzi theology. Women need to arise with new approaches and perspectives which unite both women and men, encouraging equitable relations in the church. This is attested to by Mwaura $(2013,445)$, who says that the challenge therefore continues for Africans to evolve theologies that will challenge cultural elements that do not promote women's well-being and that create a holistic community where men, women and children experience God's kingdom. Women should continue to listen to the Spirit's sayings in their specific situations and receive revelations on their leadership of the church that will provide guidance to the church in the present and in the future.

\section{References}

Dube, M. W. 2017. "Gender and the Bible in African Christianity.” Accessed July 27, 2020. https://www.researchgate.net/publication/324091898.

Clifton, Shane. 2009. “Empowering Pentecostal women.” AJPS 12 (2): 171-179.

Gabaitse, R. M. 2015. "Pentecostal Hermeneutics and the Marginalization of Women." Scriptura 114: 1-12. Accessed July 27, 2020.

http://www.scielo.org.za/scielo.php?script=sci_arttext\&pid=S2305-445X2015000100005. https://doi.org/10.7833/114-0-1043. 
Kgatle, M. S. 2017. "African Pentecostalism: the Christianity of Elias Letwaba from Early Years until his Death in 1959." Scriptura 116 (1): 1-9. Accessed July 28, 2020. https://scriptura.journals.ac.za/pub/article/view/1197/1263. https://doi.org/10.7833/116-11197.

Landman, Christina. 2013. "The (De)Construction of Religious Identity in Oral History Research in South Africa." Studia Historiae Ecclesiasticae 39 (1). Accessed July 28, 2020. http://www.scielo.org.za/scielo.php?script=sci_arttext\&pid=S10170499201300010004\&Ing=en\&tIng=en.

Langford, Joy. 2017. "Feminism and Leadership in the Pentecostal Movement." Feminist Theology 26 (1): 69-79. Accessed November 6, 2020. https://doi.org/10.1177/0966735017714402.

Masenya (ngwana' Mphahlele), M. 1996. "Proverbs 31: 10-31 in a South African Context: A Bosadi (Womanhood) Approach.” DLitt et Phil thesis, University of South Africa, Pretoria.

Masenya, Madipoane. 2005. “An African Methodology for South African Biblical Sciences: Revisiting the Bosadi Womanhood Approach.” OTE 18 (3): 741-751. Accessed August 26, 2020. https://journals.co.za/docserver/fulltext/oldtest/18/3/oldtest_v18_n3_a19.pdf? expires=1600290118\&id=id\&accname=guest \&checksum=1B6D31179622BD6F93400034 552BCE98.

Masenya, M. 2012. "Without a Voice, with a Violated Body: Rereading Judges 19 to Challenge Gender Violence in Sacred Texts." Missionalia: South African Journal of Mission Studies 40: 205-216. Accessed July 27, 2020. https://missionalia.journals.ac.za/pub/article/view/29. https://doi.org/10.7832/40-3-29.

Mkhwanazi, F. S., and T. Kgatla. 2015. "The Place of Women Ministers in the Mission of the Methodist Church of Southern Africa.” Studia Historiae Ecclesiasticae 41 (2): 180-197. Accessed August 10, 2020.09. http://www.scielo.org.za/pdf/she/v41n2/12.pdf. https://doi.org/10.25159/2412-4265/130.

Mudimeli, L. M. 2011. “The Impact of Religious and Cultural Discourses on the Leadership Development of Women in the Ministry: A vhusadzi (Womanhood) Perspective." PhD thesis, University of South Africa.

Mudimeli, L. M., and C. Landman. 2014. "The Vhusadzi Theology of Ministry.” Studia Historiae Ecclesiasticae 40: 269-283.

Mudimeli, L. M., and J. van der Westhuizen. 2019. "Unheard Voices of Women in the Bible with Implications of Empowerment in the Context of Today's Church." Acta Theologica Supplementum 27: 118-131. https://doi.org/10.18820/23099089/actat.Sup27.7.

Mwaura, P. N. 2013. "Gender and Power in African Christianity: African Instituted Churches and Pentecostal Churches.” Accessed July 29, 2020. https://repository.up.ac.za/bitstream/handle/2263/21579/017_Chapter16_p410445.pdf? sequence $=18 \&$ is Allowed $=\mathrm{y}$. 
Nadar, Sarojini. 2004. “On Being the Pentecostal Church: Pentecostal Women's Voices and Visions.” The Ecumenical Review: World Council of Churches 56 (3): 354-367. https://doi.org/10.111/j.1758-2004.tb00521.x.

Nel, M. 2017. “Attempting to Define a Pentecostal Hermeneutics.” Scriptura 114 (1): 1-21. Accessed July 22, 2020. http://www.scielo.org.za/pdf/scriptur/v114/06.pdf.

Resane, K. T. 2017. "The Centenary of Assemblies of God in South Africa: Historical Reflections on Theological Education and Ministry Formation." HTS Theological Studies 74 (1): 4853. Accessed November 6, 2020. https://doi.org/10.4102/hts.v74i1.4853.

Simoneaux, Carolyn. 2017. "Women of the Oneness Pentecostal Movement in the Twentieth and Twenty-first Century." A paper presented in partial fulfilment of Systematic Theology II, Urshan Graduate School of Theology. 